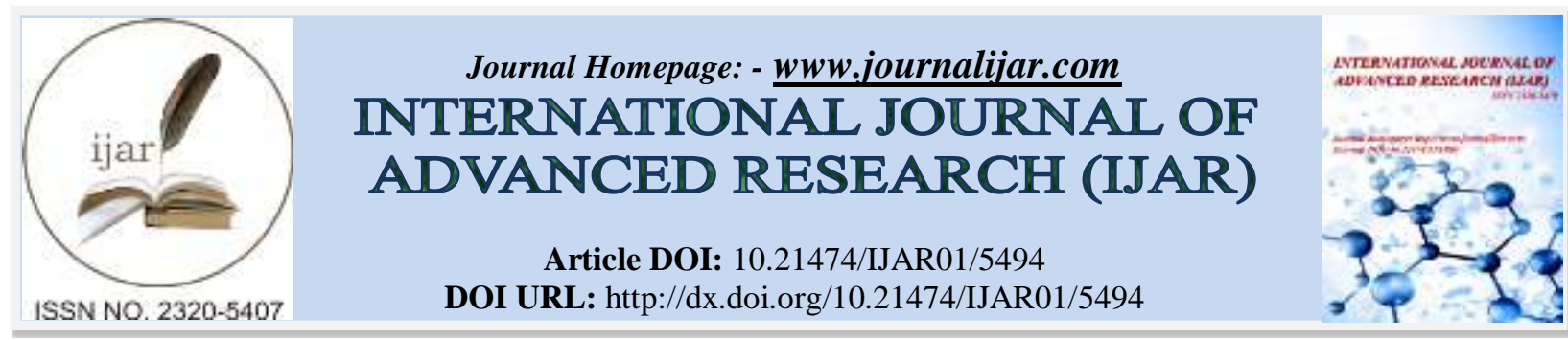

RESEARCH ARTICLE

\title{
SOURCES AND DISTRIBUTION OF ALIPHATIC AND POLYCYCLIC AROMATIC HYDROCARBONS IN SURFACE SEDIMENTS ALONG THE COASTAL CORRIDOR OF LAGUNA DE TERMINOS.
}

\author{
Nadia C. Montaño-Vera, "Alejandro Ruiz-Marín, Yunuen Canedo-López, Juan Gabriel Flores-Trujillo, Jose \\ del Carmen Zavala-Loria and Asteria Narváez-García. \\ Centro de Investigación de Ciencias Ambientales (CICA), Universidad Autónoma del Carmen, Calle 56 No.4 x Av. \\ Concordia, Col. Benito Juárez, 24180; Ciudad del Carmen, Campeche, México.
}

\section{Manuscript Info}

Manuscript History

Received: 22 July 2017

Final Accepted: 24 August 2017

Published: September 2017

Key words:-

Laguna de Términos, aliphatic

hydrocarbons, PAH, specific PAH rate.

\begin{abstract}
The Laguna de Terminos Flora and Fauna Protection Area is at the southern extreme of the Gulf of Mexico in the state of Campeche, Mexico. Its immense lagoon and mangrove habitats provide important refuge for marine, bird and mammal species. Anthropogenic activities (petroleum industry, fisheries and urban) constantly threaten the ecosystem. Aliphatic and polycyclic aromatic hydrocarbon (PAH) were determined in mangrove and coastal sediments in the Protection Area. The principal hydrocarbon sources were identified using specific PAH (fluoranthene/ fluoranthene + pyrene) rates, and concentrations compared to limits established by the United States Environmental Protection Agency for priority contaminants in surface sediment. Sediment samples were collected near the area's three main human settlements (Isla del Carmen, Isla Aguada and Sabancuy). Aliphatic hydrocarbon levels did not reach contaminating levels and were highest near urban zones and mangrove forest areas. Based on molecular weights, pyrolytic-origin PAHs were most frequent at Sabancuy (38.80\%), followed by Isla del Carmen (21.49\%) and Isla Aguada (11.21\%). Petrogenic-origin PAHs were most frequent at Sabancuy (61.71\%), followed by Isla del Carmen $(42.78 \%)$ and Isla Aguada (33.34\%). The fluoranthene / fluoranthene + pyrene index value for Sabancuy ( $>0.5$ ) suggested that sediment hydrocarbon concentrations primarily came from combustion of grasslands, forest and charcoal. At Isla Aguada, sediment hydrocarbons came from a combination of fossil fuel and grassland combustion. The very low value $(<0.4)$ at Isla del Carmen suggests heavy contributions from oil and petroleum derivative spills. Polycyclic aromatic hydrocarbons were detected in mangrove and coastal sediments within the Protection Area, but concentrations were below levels defined as contaminated.
\end{abstract}

Copy Right, IJAR, 2017,. All rights reserved.

\section{Introduction:-}

Hydrocarbon and petrochemical pollution of the environment is a pressing worldwide issue. Increasing use of diesel-powered machinery and vehicles, and spills of lubricants, fuels and chemicals are the principal means by which these contaminants enter the environment, causing significant damage to terrestrial and aquatic ecosystems. 
Because they are toxic, mutagenic and carcinogenic, particular attention is given to polycyclic aromatic hydrocarbon (PAH) contamination of the air, soil, and surface and subterranean waters. The United States Environmental Protection Agency (US EPA) classifies sixteen PAHs as priority contaminants (Qiao et al. 2006). Most are produced by incomplete combustion of organic material, especially fossil sources (Pyrolytic origin), discharge of petroleum and its derivatives (Petrogenic origin) and biogenic transformation (Diagenic origin) (Tolga-Gonul and FilizKucuksezgin 2012).

Petroleum spills have short-, medium- and long-term effects that depend on how the hydrocarbons are naturally dispersed and degraded over time. Research done after accidental spills indicates that natural elimination is very slow and petroleum deposits can persist for many years. Recovery of affected ecosystems can therefore require prolonged times periods. Many of the marine environments susceptible to hydrocarbon contamination can be considered extreme, but the microorganisms adapted to grow under these extreme conditions can be vital to the biorecovery of polluted environments.

Sediments are the main and final depositional environment of most organic contaminants, particularly the persistent organic contaminants groups (including PAHs) produced by incomplete combustion of fossil fuels. Due to their low aqueous solubility and natural hydrophobicity, hydrocarbons tend to associate with particulate matter, which eventually accumulates in sediments. Organic carbon has a high percentage of aromatic components, predominantly 2- to 6-ring compounds (Tolosa et al. 2004). The PAHs contained in soils or sediments can therefore be modified by numerous processes: biodegradation, chemical transformation, volatilization, photolysis, adsorption in the soil's solid phase, and transference to plants and animals are the principal ones (Maliszewska- Kordybach 2005).

A hydrocarbon's source and physicochemical properties determine its evolution in a marine environment. For example, petroleum-derived hydrocarbons in soluble or colloidal forms are more susceptible to photo-oxidation and volatilization than those hidden in sediments (Readman et al. 1984). Although many of the hydrocarbons in contaminated soils or sediments are susceptible to biodegradation, this susceptibility depends on factors such as optimum environmental conditions for stimulating biodegradation activity; the main hydrocarbons present in the polluting matrix; and contaminant availability to microorganisms, which is directly related to hydrocarbon molecular composition.

Hydrocarbon contamination in marine environments is mainly attributed to petroleum extraction and transport, accidental spills and events related to armed conflicts (Haapkylä et al. 2007). Of the six million tons of oil extracted annually from locations in marine environments, a far too large fraction ends up in the world's reef ecosystems (Ramade and Roche 2006). Hydrocarbon extraction has resulted in serious pollution incidents. The worst event in Mexico was the 1976 spill of over 500,000 tons of oil from the Ixtoc I platform in the Gulf of Mexico (Ramade 2000). This is not an isolated event since, before the turn of the century, five out of every six oil spills due to duct failure in marine environments occurred in the Gulf of Mexico-Caribbean Region (OSIR 1999). There have also been more recent large hydrocarbon spills on the coasts of Mexico. In 2006, the tanker Quetzalcóatl exploded at the Pajaritos Maritime Terminal spilling hydrocarbons into the Gulf, and in 2007 two platforms collided in the Gulf of Mexico causing one of the largest spills in Mexico's history. These incidents are only some of the most serious, but minor spills occur far more frequently, highlighting the need for constant monitoring of hydrocarbon contamination in exposed regions. Detection allows for timely prevention, and application of mitigation measures for possible impacts in coastal and lagoon zones.

Non-catastrophic hydrocarbon contributions to ecosystems can also occur from biological treatment of wastewater. Polycyclic aromatic hydrocarbons (PAHs) tend to accumulate in residual biological sludge, resulting in a substantial decrease in hydrophobic contaminants through sedimentation of suspended solids. Concentrations of PAHs are higher in sludges than in liquid phases. This same dynamic occurs with most of the PAHs that enter bodies of water, meaning they eventually accumulate in surface sediments, constituting a long-term contaminant reservoir (Jiries et al. 2000).

Mangrove systems are the most developed, ecologically diverse ecosystems in southeast Mexico. Located in coastal areas and estuaries, they harbor an immense biodiversity. They are also vital to preventing coastal erosion; they aid in flood control and are a primary environment for contaminant deposition and accumulation (Raza et al. 2013; Agrawala et al. 2004). Among other characteristics, mangrove has a high organic carbon content, which creates anoxic conditions in sediments with high detritus content (Raza et al. 2013). 
The Laguna de Terminos Flora and Fauna Protection Area (Área de Protección de Flora y Fauna Laguna de Términos - APFFLT) in southeast Mexico is one of the most largest natural protected areas in the country. Mangrove species protected in the APFFLT include Rhizophora mangle, Avicennia germinans, Laguncularia racemosa and Conacarpus erectus, some of which can grow to over $20 \mathrm{~m}$ tall. Two wetlands ecosystems occupy the largest proportion of the Area's lacustrine zones: the popal community, dominated by Thalia geniculata and occurring in areas with greater areas of standing water; and the tular community, dominated by Thypa latifolia and Cyperus articulatum (CONANP). Common aquatic plant species in both communities include Pistia stratiotes and Nymphaea sp.

A large portion of the APFFLT is contained within Carmen Municipality, which had a population of 221091 hab in 2010, mostly distributed in the urban zones of Ciudad del Carmen, Isla Aguada and Sabancuy (INEGI 2010). Economic activities in the municipality include livestock raising, farming and fishing, but the primary incomegenerating activity is the oil industry (exploration, perforation and extraction). Concentrated in Ciudad del Carmen, this industry is responsible for almost $95 \%$ of Mexico's crude oil production and $80 \%$ of its natural gas production. Its growth has accelerated regional population growth and use of natural resources for urban and industrial uses. Water use has increased rapidly as has wastewater discharge, bringing negative impacts to bodies of water adjacent the Laguna de Terminos (Ruiz-Marín et al. 2014). Fishing is also economically important in the region and the proximity of these two activities has caused social conflict due to hydrocarbon contamination of fishing grounds and coastal areas. Petroleos Mexicanos (PEMEX), the state-owned corporation responsible for oil reserve exploration, and oil and petroleum processing, refining and distribution, has collaborated with environmental programs aimed at decreasing oil industry pollution levels (Iturbe et al. 2007).

Mangrove ecosystems in southeast Mexico, particularly those in the APFFLT, are under constant threat from anthropogenic pollutants, a threat that will likely increase in the future. Contamination of mangrove sediments is especially acute from pyrolytic- and petrogenic-source PAHs (Tam et al. 2001; Zhi-qiang et al. 2005; Cavalcante et al. 2009). The present study aim was to describe PAH composition in mangrove sediments throughout the coastal zone of the APFFLT, identify the main sources of any PAHs, quantify their concentrations and compare these to the maximum levels recommended by the US EPA for priority contaminant hydrocarbons in surface sediments.

\section{Materials and Methods:-}

Study area, sampling and chemical analysis:-

Of the 706147 ha total area of the APFFLT, 351,582 ha are terrestrial and 353,434 ha are aquatic. Located at the southern extreme of the Gulf of Mexico, in the state of Campeche (Fig. 1), it is considered one of the most extensive estuarine lagoon ecosystems in Mexico (200,108 ha of lagoon surface, including associated lagoon and fluvial systems). The Area's coastal plain forms part of the deltaic plain complex of the Grijalva-Usumacinta drainage system, which produces the highest freshwater and sedimentary discharges into the ocean of any system in Mexico.

The Laguna de Terminos ( $18^{\circ} 24^{\prime}$ and $19^{\circ} 00^{\prime} \mathrm{N} ; 9^{\circ} 15^{\prime}$ and $\left.92^{\circ} 00^{\prime} \mathrm{W}\right)$ is the largest coastal lagoon in Mexico $(70 \mathrm{x}$ $28 \mathrm{~km} ; 1566.5 \mathrm{~km}^{2} ; 3.5 \mathrm{~m}$ average depth) (De la Lanza Espino et al., 1999). The $37.5 \mathrm{~km}$-long island of Isla del Carmen separates it from the Gulf of Mexico, with which it connects via one inlet in the northeast (Puerto Real inlet) and another to the northwest (Carmen inlet). Ciudad del Carmen is located on this island. It is the largest human settlement inside the APFFLT and it is here that most of the state's oil exploration, drilling and extraction industries are located.

Carmen Municipality also encompasses the coastal settlements of Isla Aguada (pop. 6204) and Sabancuy (pop. 7286) (INEGI 2010). Surrounded by the waters of the Gulf of Mexico and the Laguna de Terminos, the main economic activity on the island of Isla Aguada is fishing. Sabancuy is located at the northeastern extreme of the Laguna de Terminos, about $85 \mathrm{~km}$ from Ciudad del Carmen. The coast in front of this settlement is known to support threated species such as the Hawksbill sea turtle (Eretmochelys imbricata). 

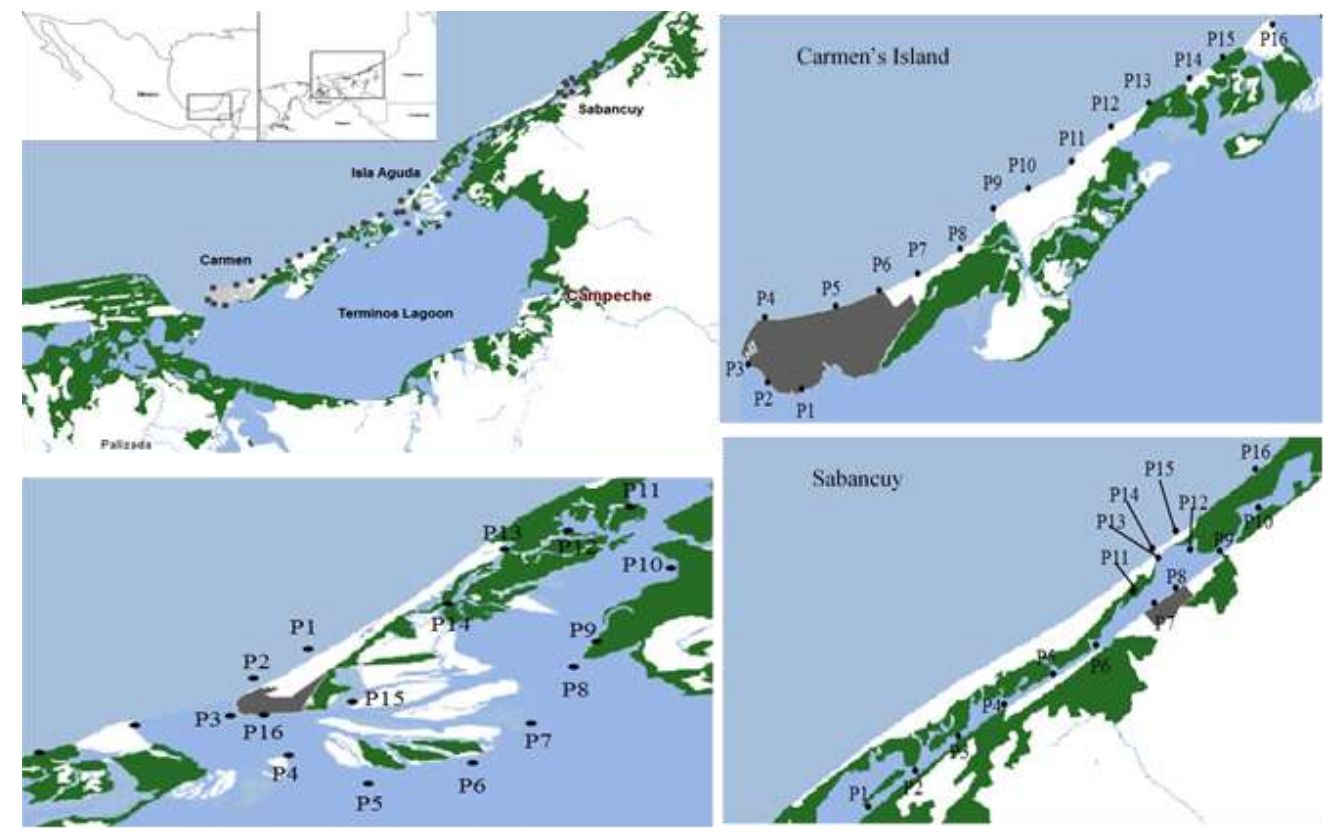

Fig. 1:- Study area and sampling stations along the Isla del Carmen-Isla Aguada-Sabancuy coastal lagoon corridor.

A total of 48 sampling stations were placed along the Isla del Carmen-Isla Aguada-Sabancuy coastal lagoon corridor, sixteen in each area. At each station, $3 \mathrm{~cm}$ of surface sediment were collected in triplicate with a Van Veen dredge. Samples were placed in glass flasks previously treated with an acidic solution and then stored at $-4{ }^{\circ} \mathrm{C}$ for later analysis. Before running hydrocarbon analyses, the samples were dried in an oven at $60{ }^{\circ} \mathrm{C}$, homogenized with a mortar and finally sifted $(0.5 \mu \mathrm{m}$ particle size). After drying, approximately $20 \mathrm{~g}$ of each sample were weighed out and placed in fiberglass thimbles. Hydrocarbon extraction was done with a Soxhlet extractor using $200 \mathrm{ml}$ dichloromethane in a flat-bottomed round flask under reflux for eight hours. After the allotted time, the extracts were cooled and any remaining solvent evaporated using Snyder columns until attaining a $5 \mathrm{ml}$ extract volume. The extract was placed in amber vials and further concentrated to a $1.5 \mathrm{ml}$ volume using nitrogen flow. Extraction procedure quality control was accomplished by including a pure sand standard in each sample lot to assess the accuracy of our work. All the result were within the expected certified range (95\% confidence interval). Limits of detection (LOD) were determined by spiking blank samples with a standard solution $\left(5 \mathrm{ng} \mu \mathrm{l}^{-1}\right)$ of the determined aliphatic hydrocarbons and PAHs, and calculated considering the ratio $\mathrm{S} / \mathrm{N}>2$. LOD in the case of PAHs were between 0.5 and $1.0 \mathrm{ng} \mathrm{g}^{-1}$, while in the case of aliphatic hydrocarbons, they were at $0.5 \mathrm{ng} \mathrm{g}^{-1}$.

\section{Hydrocarbon analysis:-}

Purification and separation of the aliphatic and aromatic fractions was done using a glass column with a Teflon valve. A glass wool plug was inserted and the column dry packed in this order: $1 \mathrm{~cm}$ sodium sulphate; $10 \mathrm{~g}$ alumina; 20 g partially deactivated silica gel; $1 \mathrm{~cm}$ sodium sulphate; and finally $1 \mathrm{~cm}$ copper dust. Thirty milliliters (30 ml) methylene chloride were then added and the valve opened to a point that allowed flow but ensured that the column always contained solvent. When the solvent reached the copper surface, a concentrated sample extract was immediately added. Elution of the first fraction (aliphatic hydrocarbons) was done with $100 \mathrm{ml}$ hexane. This was followed by elution of the second fraction (aromatic hydrocarbons) with $100 \mathrm{ml}$ hexane and $100 \mathrm{ml}$ methylene chloride. Both fractions were concentrated by evaporating the solvent with pure (99.99\%) nitrogen flow until reaching $1.5 \mathrm{ml}$ volume. These concentrated fractions were stored for later gas chromatography analysis and quantification.

Hydrocarbon concentration was measured by sediment sample extraction following the regulation Mexican method (NOM-138-SEMARNAT/SS) and the 9071-EPA method. The hydrocarbon fractions were analyzed with a gas chromatographer (Agilent Technology, model 7890) equipped with a flame ionization detector, and a $30 \mathrm{~m}$ x 0.32 $\mathrm{mm}$ capillary column with a $0.25 \mu \mathrm{m}$ thick layer. The transport gas (nitrogen) was injected at a rate of $1.5 \mathrm{~mL} \mathrm{~min}^{-1}$. Injector temperature was $350{ }^{\circ} \mathrm{C}$ and detector temperature was $360{ }^{\circ} \mathrm{C}$. The oven heating program was $50{ }^{\circ} \mathrm{C}$ for 4 min; followed by $10{ }^{\circ} \mathrm{C} \min ^{-1}$ increments until $300{ }^{\circ} \mathrm{C}$ for 15 mins. Analyses were run for twelve PAH congeners: 
acenaphthene; 2-methylnaphthene; fenanthrene; anthracene; fluorene; fluoranthene; pyrene; chrysene; benzo[k]fluoranthene; indeno [1,2,3-cd]pyrene; benzo[g,h,i]perylene; and dibenzo[a,h]anthracene.

\section{Statistical analysis:-}

The mean values were compared using an analysis of variance (ANOVA) test, with a $p$ value $\leq 0.05$ among sample station. All statistical analysis were performed using a software (StatSoft Inc., Tulsa, OK, USA). The Tukey test ( $p$ $\leq 0.05$ ) was applied when results showed significant differences.

\section{Results and Discussion:-}

\section{Aliphatic hydrocarbons:-}

Total aliphatic hydrocarbons content in the sediments varied $(\mathrm{P}<0.05)$ between sampling stations and within the overall study area. At the Isla del Carmen stations values ranged from 3.33 to $56.56 \mu \mathrm{g} \mathrm{g}^{-1} \mathrm{dwt}$ were obtained; for Isla Aguada showed ranged from 11.4 to $108.11 \mu \mathrm{g} \mathrm{g}^{-1} \mathrm{dwt}$; and for Sabancuy the ranged were from 38.4 to 107.2 $\mu \mathrm{g} \mathrm{g}^{-1} \mathrm{dwt}$ (Fig. 2). At each location, the stations with the highest values were probably associated with runoff from residential and/or industrial zones. In according to Volman et al. (1992), concentrations greater than $500 \mu \mathrm{g} \mathrm{g}^{-1} \mathrm{dwt}$ are generally indicative of significant contamination levels while those below $10 \mu \mathrm{g} \mathrm{g}^{-1} \mathrm{dwt}$ are considered uncontaminated, therefore, sediment sample concentrations in the present study had relatively low levels, although the presence of aliphatic hydrocarbons and the higher hydrocarbon levels apparently generated by anthropogenic activities highlights the need for intervention. Hydrocarbon contamination prevention and mitigation programs are needed to reduce and eliminate negative impacts in refuge areas of the APFFLT.

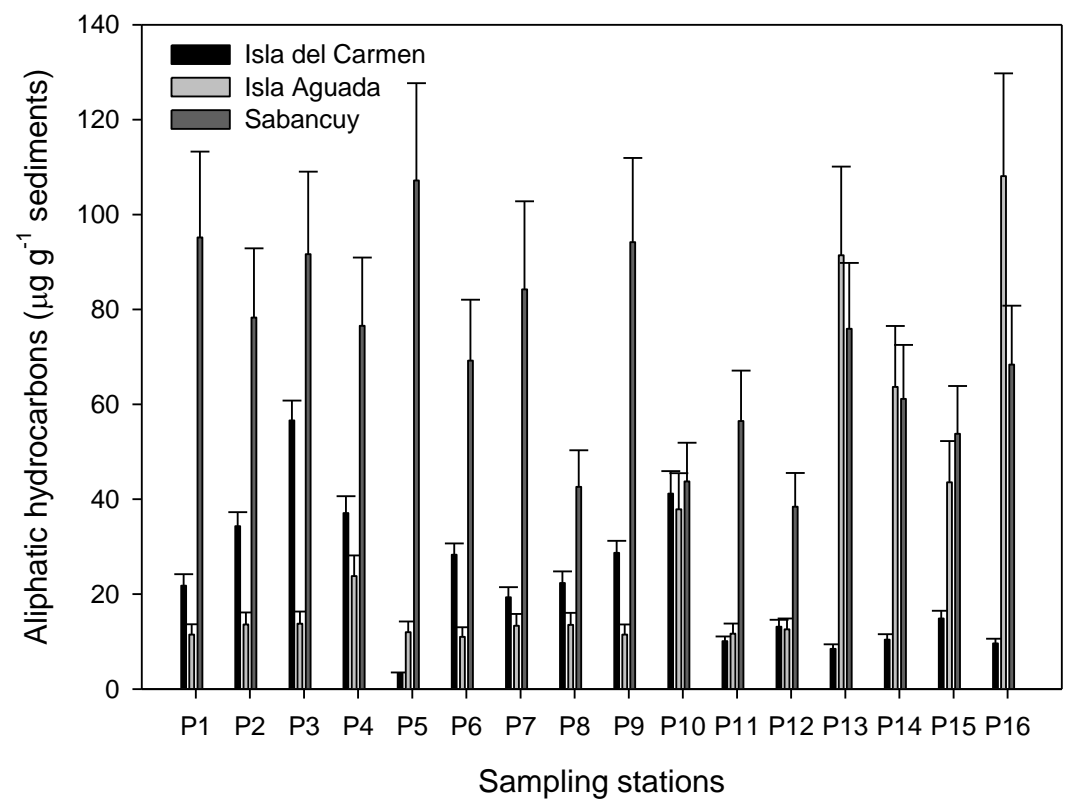

Fig. 2:- Aliphatic hydrocarbons concentrations (dry weight base) along the Isla del Carmen-Isla Aguada-Sabancuy coastal lagoon corridor (bars: mean \pm standard deviation).

The highest concentrations among the Isla del Carmen stations were at $P_{1}, P_{2}$ and $P_{3}\left(21.8-56.56 \mu g^{-1}\right.$ dwt), nearest the densest urban zone. At Isla Aguada, the highest value $\left(108.11 \mu \mathrm{g} \mathrm{g}^{-1} \mathrm{dwt}\right)$ was recorded at $\mathrm{P}_{16}$ nearest the urban zone, with intermediate values at $\mathrm{P}_{10}-\mathrm{P}_{15}\left(37.8-91.42 \mu \mathrm{g} \mathrm{g}{ }^{-1} \mathrm{dwt}\right)$ inside mangrove channels and forests. High concentrations at Sabancuy were observed at $\mathrm{P}_{1}-\mathrm{P}_{6}\left(69.18-107.2 \mu \mathrm{g} \mathrm{g} \mathrm{g}^{-1} \mathrm{dwt}\right)$ in channels where seagrass and mangrove forest favor sediment (and hydrocarbon) retention (Fig. 2).

The value range observed here is higher than reported elsewhere in sediments: east coast of the Aegean Sea ( 0.52 to $4.85 \mu \mathrm{g} \mathrm{g}^{-1} \mathrm{dwt}$ ) (Gonul and Kucuksezgin 2012); Ukraine (2.1 to $6.6 \mu \mathrm{g} \mathrm{g}^{-1} \mathrm{dwt}$ ) (Readman et al. 2002); the eastern Mediterranean (0.5 - $5.7 \mu \mathrm{g} \mathrm{g}^{-1} \mathrm{dwt}$ ) (Gogou et al. 2000); and Antarctica (0.25 - $23 \mu \mathrm{g} \mathrm{g}^{-1} \mathrm{dwt}$ ) (Martins et al. 2004). However, it is within the range for South America overall $\left(21-2,622 \mu \mathrm{g} \mathrm{g}^{-1} \mathrm{dwt}\right.$ ) (Bicego et al. 2006), and for Ushuaia Bay, Argentina (5.5-1185 $\mu \mathrm{g} \mathrm{g}^{-1} \mathrm{dwt}$ ), a protected area with evaluated biodiversity and conditions apt for 
aquaculture, but which suffers anthropogenic impacts from tourism, trade, industrial development, maritime traffic and urban and industrial waste discharge (Commendatore et al. 2012). The present concentration value range is also quite similar to that reported for the coast northeast of Havana, Cuba (5.5 to $225.7 \mu \mathrm{g} \mathrm{g}^{-1} \mathrm{dwt}$ ), where the highest concentrations were recorded in an area of intense oil exploration and the lowest near areas used for camping and other recreational activities, and located far from oil wells (Companioni et al. 2011).

\section{Polycyclic aromatic hydrocarbons (PAHs):-}

Concentrations of the twelve evaluated PAHs $\left(\sum \mathrm{PAH}\right)$ in sediments from the sampling stations varied between stations and study areas. The value range was $4.98-99.22 \mathrm{ng} \mathrm{g}^{-1} \mathrm{dwt}$ at Isla del Carmen, $22.22-90.35 \mathrm{ng} \mathrm{g}^{-1} \mathrm{dwt}_{\text {at }}$ Isla Aguada, and $16.95-54.04 \mathrm{ng} \mathrm{g}^{-1} \mathrm{dwt}$ at Sabancuy (Fig. 3). Given the prevalence of industrial activity and the high population densities in these three areas, high $\mathrm{PAH}$ concentrations are to be expected. However, the concentrations observed at the mangrove sediment and coastal zone stations were lower than those reported for highly polluted sites such as the Lenga estuary (290-6,118 $\mathrm{ng} \mathrm{g}^{-1} \mathrm{dwt}$ ) (Pozo et al. 2011), the Yellow River estuary (111-205 $\mathrm{ng} \mathrm{g}^{-1} \mathrm{dwt}$ ) (Hu et al. 2014), and the Jiulong River estuary (280-1,074 $\mathrm{ng} \mathrm{g}^{-1} \mathrm{dwt}$ ) (Tian et al. 2008). In a study of mangrove zones in Hong Kong, China, mangrove PAH concentrations were found to be higher than in the marine sediments of Hong Kong's ports, with a greater content of low molecular-weight PAHs such as naphthalenes, fluorine and phenanthrene (356-11,098 $\mathrm{ng} \mathrm{g}^{-1} \mathrm{dwt}$ ) (Tam et al. 2001).

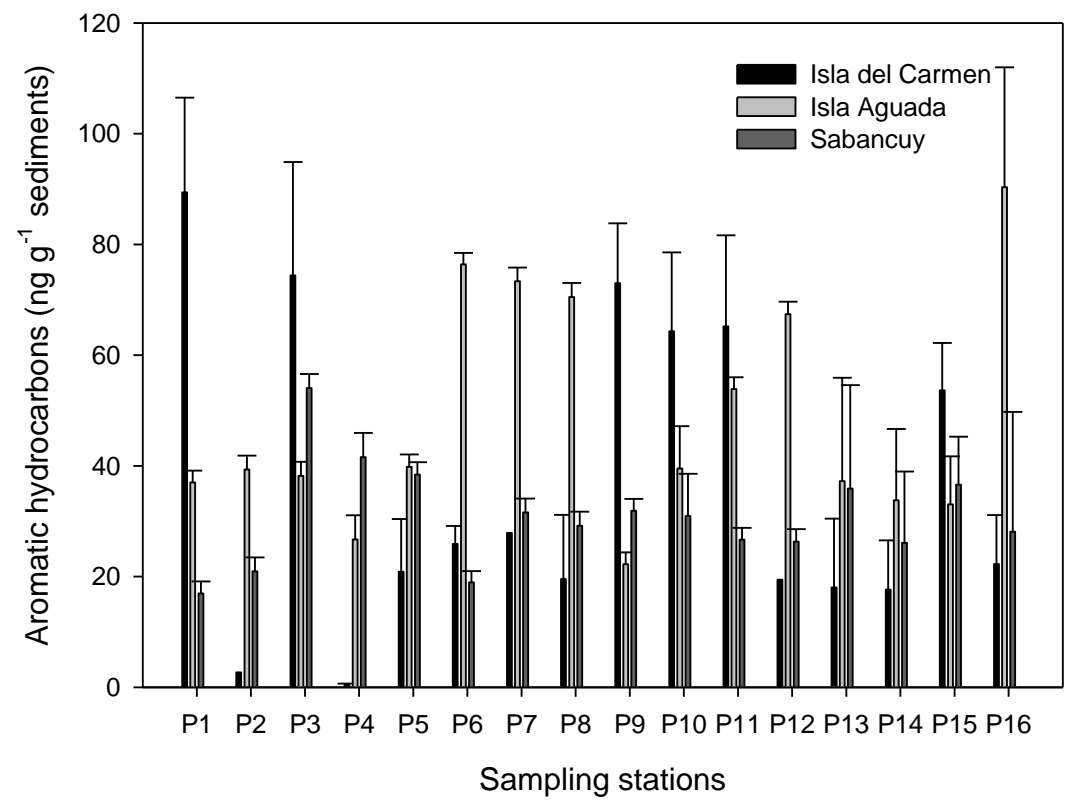

Fig. 3:- Polycyclic aromatic hydrocarbons (PAH) concentrations (dry weight base) along the Isla del Carmen-Isla Aguada-Sabancuy coastal lagoon corridor (bars: mean \pm standard deviation).

To analyze the hydrocarbons retained in the sediments and identify their sources, the PAHs were classified into two groups: low molecular weight (LMW) and high molecular weight (HMW). For the Isla del Carmen area, a larger proportion of $\sum \mathrm{PAH}$ was represented by LMW $\left(67.40 \%\right.$; average $\left.=27.83 \mu \mathrm{g} \mathrm{g}^{-1} \mathrm{dwt}\right)$ than HMW $(32.60 \%$; average: $13.45 \mu \mathrm{g} \mathrm{g}^{-1} \mathrm{dwt}$ ). This indicates the area experiences greater accumulation of the LMW hydrocarbons associated with urban zones and industrial activity. Concentrations of both kinds of PAHs were lower in stations near tourist and swimming areas and further from urban and industrial zones.

Low molecular-weight (LMW) PAHs were present near the Ciudad del Carmen urban zone (61.14 $\mathrm{ng} \mathrm{g}^{-1} \mathrm{dwt}_{\text {at }} \mathrm{P}_{1}$ ) and the island's commercial/industrial zone (17.97 - $65.19 \mathrm{ng} \mathrm{g}^{-1} \mathrm{dwt}$ at stations $\mathrm{P}_{5}, \mathrm{P}_{7}, \mathrm{P}_{8}, \mathrm{P}_{10}$ and $\left.\mathrm{P}_{11}\right)$. Stations furthest from anthropogenic activities (e.g. recreation areas) had the lowest concentrations $\left(16.11-37.22 \mu \mathrm{g} \mathrm{g}^{-1} \mathrm{dwt}\right.$ at $\mathrm{P}_{12}$ to $\mathrm{P}_{16}$ ). This suggests that salinity may play an important role in lowering PAH concentrations (Table 1). Similar results have been reported for the Yangtze River estuary, where PAH concentrations in surface sediment decreased with proximity to ocean waters ( $\mathrm{Li}$ et al. 2012, Wang et al. 2015). The highest HMW PAH concentrations at Isla del Carmen were at stations nearest the city center $\left(4.98-56.58 \mathrm{ng} \mathrm{g}^{-1} \mathrm{dwt}\right.$ at $\left.\mathrm{P}_{2}-\mathrm{P}_{4}\right)$ and the 
commercial/industrial zone (17.54 - $31.66 \mathrm{ng} \mathrm{g}^{-1} \mathrm{dwt}$ at $\mathrm{P}_{6}$ and $\left.\mathrm{P}_{9}\right)$. Stations further from anthropogenic activities exhibited the lowest influence from HMW PAHs $\left(0.73-17.71 \mu \mathrm{g} \mathrm{g}^{-1} \mathrm{dwt}\right.$ at $\mathrm{P}_{12}$ to $\left.\mathrm{P}_{16}\right)$ (Table 1).

For Isla Aguada, the LMW PAHs accounted for $69.68 \%$ (average $=34.05 \mathrm{ng} \mathrm{g}^{-1} \mathrm{dwt}$ ) of $\sum$ PAH and HMW PAHs for $30.0 \%$ (average $=14.6 \mathrm{ng} \mathrm{g}^{-1} \mathrm{dwt}$ ) (Table 2). The highest LMW PAHs concentrations were recorded at stations in the shallow flood zone $\left(60.76-63.36 \mathrm{ng} \mathrm{g}^{-1}\right.$ dwt at $\mathrm{P}_{6}, \mathrm{P}_{7}$ and $\left.\mathrm{P}_{8}\right)$ and inside channels in the mangrove forest (46.99$68.68 \mathrm{ng} \mathrm{g}^{-1} \mathrm{dwt}$ at $\mathrm{P}_{11}, \mathrm{P}_{12}$ and $\left.\mathrm{P}_{16}\right)$. Concentrations were lower at stations nearer the town $\left(5.05-26.54 \mathrm{ng} \mathrm{g}^{-1} \mathrm{dwt}\right.$ at $\mathrm{P}_{1}$ a $\mathrm{P}_{5}$ ). High molecular weight (HMW) PAHs were primarily present at stations near the town (11.66 -17.57 $\mathrm{ng} \mathrm{g}^{-1}$ dwt at $P_{1}-P_{5}$ ), in low flooded areas $\left(9.27-18.31 \mathrm{ng} \mathrm{g}^{-1} \mathrm{dwt}\right.$ at $\mathrm{P}_{9}$ and $\mathrm{P}_{10}$ ), and those near mangrove forest (19.42 $21.33 \mathrm{ng} \mathrm{g}^{-1} \mathrm{dwt}$ at $\left.\mathrm{P}_{13}, \mathrm{P}_{14}, \mathrm{P}_{15}\right)$.

In contrast to the two areas above, HMW PAHs accounted for most $(75.4 \%)$ of $\sum \mathrm{PAH}$ for Sabancuy (average $=$ $23.27 \mathrm{ng} \mathrm{g}^{-1} \mathrm{dwt}$ ) and LMW PAHs for a lesser proportion (24.6\%; average $=7.61 \mathrm{ng} \mathrm{g}^{-1} \mathrm{dwt}$ ) (Table 3). Higher HMW PAH concentrations were observed at stations in the mangrove forest $\left(13.37-32.0 \mathrm{ng} \mathrm{g}^{-1} \mathrm{dwt}\right)$, the Sabancuy Lagoon $\left(18.3-24.89 \mathrm{ng} \mathrm{g}^{-1} \mathrm{dwt}\right)$, and the coastal zone $\left(19.58-27.31 \mathrm{ng} \mathrm{g}^{-1} \mathrm{dwt}\right)$. While for the LMW PAH concentrations were recorded at stations in the mangrove forest (3.57-16.23 $\mathrm{ng} \mathrm{g}^{-1} \mathrm{dwt}$ at $\mathrm{P}_{1}$ to $\mathrm{P}_{6}$ ), and the lagoon interior (5.86 - $24.89 \mathrm{ng} \mathrm{g}^{-1} \mathrm{dwt}$ at $\mathrm{P}_{7}$ to $\mathrm{P}_{12}$ ), with lower levels in the coastal zone (5.86 - $9.77 \mathrm{ng} \mathrm{g}^{-1} \mathrm{dwt}$ at $\mathrm{P}_{13}$ to $\left.\mathrm{P}_{16}\right)$.

Table 1:- Polycyclic aromatic hydrocarbon (PAH) concentrations $\left(\mathrm{ng} \mathrm{g}^{-1} \mathrm{dw}\right)$ at sampling stations in the Isla del Carmen area.

\begin{tabular}{|c|c|c|c|c|c|c|c|c|c|c|c|c|c|c|c|c|}
\hline & \multicolumn{4}{|c|}{ Ciudad del Carmen } & \multicolumn{7}{|c|}{ Industrial/Commercial Zone } & \multicolumn{5}{|c|}{ Recreation Areas } \\
\hline PAHs & P1 & $\mathbf{P 2}$ & P3 & P4 & P5 & P6 & P7 & P8 & P9 & $\begin{array}{l}\text { P1 } \\
\text { 0 }\end{array}$ & $\begin{array}{l}\text { P1 } \\
1\end{array}$ & $\begin{array}{l}\text { P1 } \\
2\end{array}$ & $\begin{array}{l}\mathbf{P 1} \\
\mathbf{3}\end{array}$ & $\begin{array}{l}\text { P1 } \\
4\end{array}$ & $\begin{array}{l}\text { P1 } \\
5\end{array}$ & $\begin{array}{l}\text { P1 } \\
6\end{array}$ \\
\hline Acenaphthene & $\begin{array}{l}47 . \\
62\end{array}$ & nd & nd & nd & $\begin{array}{l}17 . \\
18\end{array}$ & nd & nd & $\begin{array}{l}17 . \\
97\end{array}$ & $\begin{array}{l}18 . \\
15\end{array}$ & $\begin{array}{l}35 . \\
68\end{array}$ & $\begin{array}{l}44 . \\
23\end{array}$ & $\begin{array}{l}19 . \\
42\end{array}$ & $\begin{array}{l}17 . \\
82\end{array}$ & nd & $\begin{array}{l}17 . \\
93\end{array}$ & nd \\
\hline Fluorene & $\begin{array}{l}13 . \\
51\end{array}$ & nd & $\begin{array}{l}28 . \\
25\end{array}$ & nd & $\begin{array}{l}3.6 \\
9 \\
\end{array}$ & $\begin{array}{l}15 . \\
24\end{array}$ & $\begin{array}{l}27 . \\
88\end{array}$ & $\mathrm{nd}$ & $\begin{array}{l}25 . \\
08\end{array}$ & $\begin{array}{l}21 . \\
45\end{array}$ & $\begin{array}{l}20 . \\
96\end{array}$ & $\mathrm{nd}$ & $\begin{array}{l}0.2 \\
3 \\
\end{array}$ & $\begin{array}{l}16 . \\
11\end{array}$ & $\begin{array}{l}19 . \\
28\end{array}$ & $\begin{array}{l}17 . \\
61\end{array}$ \\
\hline Fluoranthene & nd & nd & $\begin{array}{l}2.8 \\
1\end{array}$ & $\begin{array}{l}0.0 \\
42\end{array}$ & nd & nd & nd & $\begin{array}{l}1.5 \\
9\end{array}$ & nd & nd & nd & nd & nd & $\begin{array}{l}0.1 \\
4\end{array}$ & nd & $\begin{array}{l}2.8 \\
2\end{array}$ \\
\hline Pyrene & $\begin{array}{l}9.8 \\
2\end{array}$ & $\begin{array}{l}9.6 \\
7\end{array}$ & $\begin{array}{l}10 . \\
41\end{array}$ & $\begin{array}{l}4.5 \\
5\end{array}$ & $\begin{array}{l}9.4 \\
7\end{array}$ & $\begin{array}{l}6.8 \\
9\end{array}$ & $\begin{array}{l}4.7 \\
3\end{array}$ & $\begin{array}{l}0.8 \\
0\end{array}$ & $\begin{array}{l}1.8 \\
8\end{array}$ & $\begin{array}{l}1.5 \\
9\end{array}$ & $\begin{array}{l}0.2 \\
6\end{array}$ & $\begin{array}{l}0.7 \\
4\end{array}$ & $\begin{array}{l}0.7 \\
3\end{array}$ & $\begin{array}{l}1.3 \\
7\end{array}$ & $\begin{array}{l}1.3 \\
1\end{array}$ & $\begin{array}{l}1.7 \\
2\end{array}$ \\
\hline $\begin{array}{l}\text { Dibenzo }(\mathrm{A}, \mathrm{H}) \\
\text { Anthracene }\end{array}$ & nd & nd & nd & nd & nd & nd & nd & nd & $\begin{array}{l}3.0 \\
8\end{array}$ & nd & nd & nd & nd & nd & $\begin{array}{l}0.7 \\
4\end{array}$ & nd \\
\hline $\begin{array}{l}\text { Indeno }(1,2,3- \\
\text { CD) Pyrene }\end{array}$ & $\begin{array}{l}28 . \\
26\end{array}$ & $\begin{array}{l}2.6 \\
9\end{array}$ & $\begin{array}{l}43 . \\
35\end{array}$ & $\begin{array}{l}0.3 \\
9\end{array}$ & nd & $\begin{array}{l}10 . \\
64\end{array}$ & nd & nd & $\begin{array}{l}26 . \\
7\end{array}$ & $\begin{array}{l}7.1 \\
7\end{array}$ & nd & nd & nd & $\begin{array}{l}1.3 \\
9\end{array}$ & $\begin{array}{l}15 . \\
67\end{array}$ & $\begin{array}{l}1.8 \\
5\end{array}$ \\
\hline$\sum \mathrm{PAH}$ & $\begin{array}{l}99 . \\
22\end{array}$ & $\begin{array}{l}12 . \\
37\end{array}$ & $\begin{array}{l}84 . \\
82\end{array}$ & $\begin{array}{l}4.9 \\
8\end{array}$ & $\begin{array}{l}30 . \\
33\end{array}$ & $\begin{array}{l}32 . \\
78\end{array}$ & $\begin{array}{l}32 . \\
60\end{array}$ & $\begin{array}{l}20 . \\
38\end{array}$ & $\begin{array}{l}74 . \\
90\end{array}$ & $\begin{array}{l}65 . \\
89\end{array}$ & $\begin{array}{l}65 . \\
45\end{array}$ & $\begin{array}{l}20 . \\
16\end{array}$ & $\begin{array}{l}18 . \\
77\end{array}$ & $\begin{array}{l}19 . \\
01\end{array}$ & $\begin{array}{l}54 . \\
93\end{array}$ & $\begin{array}{l}24 . \\
0\end{array}$ \\
\hline$\sum \mathrm{LMW}$ & $\begin{array}{l}61 . \\
14\end{array}$ & 0 & $\begin{array}{l}28 . \\
25\end{array}$ & 0 & $\begin{array}{l}20 . \\
86\end{array}$ & $\begin{array}{l}15 . \\
24\end{array}$ & $\begin{array}{l}27 . \\
88\end{array}$ & $\begin{array}{l}17 . \\
97\end{array}$ & $\begin{array}{l}43 . \\
24\end{array}$ & $\begin{array}{l}57 . \\
13\end{array}$ & $\begin{array}{l}65 . \\
19\end{array}$ & $\begin{array}{l}19 . \\
42\end{array}$ & $\begin{array}{l}18 . \\
04\end{array}$ & $\begin{array}{l}16 . \\
11\end{array}$ & $\begin{array}{l}37 . \\
22\end{array}$ & $\begin{array}{l}17 . \\
61\end{array}$ \\
\hline$\sum \mathrm{HMW}$ & $\begin{array}{l}38 . \\
08\end{array}$ & $\begin{array}{l}12 . \\
37\end{array}$ & $\begin{array}{l}56 . \\
58\end{array}$ & $\begin{array}{l}4.9 \\
8 \\
\end{array}$ & $\begin{array}{l}9.4 \\
7 \\
\end{array}$ & $\begin{array}{l}17 . \\
54\end{array}$ & $\begin{array}{l}4.7 \\
3 \\
\end{array}$ & $\begin{array}{l}2.4 \\
0\end{array}$ & $\begin{array}{l}31 . \\
66\end{array}$ & $\begin{array}{l}8.7 \\
6 \\
\end{array}$ & $\begin{array}{l}0.2 \\
6 \\
\end{array}$ & $\begin{array}{l}0.7 \\
4 \\
\end{array}$ & $\begin{array}{l}0.7 \\
3 \\
\end{array}$ & $\begin{array}{l}2.9 \\
1 \\
\end{array}$ & $\begin{array}{l}17 . \\
71\end{array}$ & $\begin{array}{l}6.3 \\
9 \\
\end{array}$ \\
\hline$\sum \mathrm{LMW} / \sum \mathrm{HMW}$ & $\begin{array}{l}1.6 \\
0\end{array}$ & $\begin{array}{l}0.0 \\
81\end{array}$ & $\begin{array}{l}0.4 \\
9 \\
\end{array}$ & $\begin{array}{l}0.2 \\
0 \\
\end{array}$ & $\begin{array}{l}2.2 \\
0 \\
\end{array}$ & $\begin{array}{l}0.8 \\
69 \\
\end{array}$ & $\begin{array}{l}5.8 \\
9 \\
\end{array}$ & $\begin{array}{l}7.4 \\
8 \\
\end{array}$ & $\begin{array}{l}1.3 \\
6 \\
\end{array}$ & $\begin{array}{l}6.5 \\
2 \\
\end{array}$ & $\begin{array}{l}25 \\
0.7 \\
\end{array}$ & $\begin{array}{l}26 . \\
24\end{array}$ & $\begin{array}{l}24 . \\
71\end{array}$ & $\begin{array}{l}5.5 \\
3 \\
\end{array}$ & $\begin{array}{l}2.1 \\
0 \\
\end{array}$ & $\begin{array}{l}2.7 \\
5 \\
\end{array}$ \\
\hline
\end{tabular}

nd $=$ no data

Possible accumulation processes and sources can be suggested based on this analysis of PAHs in coastal and mangrove sediments. Evaluating sediment PAHs content can help to indicate their presence in an aquatic medium. Sediments have a substantial effect on temporal PAH entrance patterns and thus provide a good geographic scheme when environmental patterns are known (e.g. current patterns, sediment origins, sedimentation rates, etc.). In the present results, PAH concentrations decreased at stations experiencing greater marine water influence, suggesting that riverine discharge and urban run-off are the most probable sources of the PAHs found in the sampled sediments.

The decrease in PAH concentrations with proximity to marine waters can be explained by two phenomena. First, aquatic grass and mangrove zones promote particle sedimentation, which is why they are known to contribute 
substantially to flood control and reduction of coastal erosion (Agrawala et al. 2004). Second, aerobic biodegradation processes occur in the surface layer of sediments. This has been reported in studies showing increasing PAH concentrations with flow towards the ocean due to sedimentation/accumulation and microbiological degradation in the aerobic surface layers of mangrove sediment (DeLaune et al. 1980; Raza et al. 2013). Biodegradation rates of PAHs may therefore decrease as salinity increases (Tam et al. 2001; Chen et al. 2009; Raza et al. 2013), since high salinity can reduce microbe metabolic rates (Haritash and Kaushik 2009). The lower PAH values observed for the stations with salinity in the $30-35$ ppt range were therefore probably the result of the degradation of and accumulated petrogenic- and pyrolytic-origin PAHs.

Table 2:- Polycyclic aromatic hydrocarbon (PAH) concentrations $\left(\mathrm{ng} \mathrm{g}^{-1} \mathrm{dw}\right)$ at sampling stations in the Isla Aguada area.

\begin{tabular}{|c|c|c|c|c|c|c|c|c|c|c|c|c|c|c|c|c|}
\hline & \multicolumn{5}{|c|}{ Town } & \multicolumn{5}{|c|}{ Flooded Zone } & \multicolumn{6}{|c|}{ Mangrove Forest } \\
\hline PAHs & P1 & $\mathbf{P 2}$ & $\mathbf{P 3}$ & P4 & P5 & P6 & P7 & $\mathbf{P 8}$ & P9 & $\begin{array}{l}\text { P1 } \\
\text { 0 }\end{array}$ & $\begin{array}{l}\text { P1 } \\
1\end{array}$ & $\begin{array}{l}\text { P1 } \\
2\end{array}$ & $\begin{array}{l}\text { P1 } \\
\mathbf{3}\end{array}$ & $\begin{array}{l}\text { P1 } \\
4\end{array}$ & $\begin{array}{l}\text { P1 } \\
5\end{array}$ & $\begin{array}{l}\text { P1 } \\
6\end{array}$ \\
\hline Acenaphthene & nd & nd & nd & nd & nd & $\begin{array}{l}48 . \\
06\end{array}$ & $\begin{array}{l}53 . \\
25 \\
\end{array}$ & $\begin{array}{l}56 . \\
39\end{array}$ & nd & nd & $\begin{array}{l}41 . \\
25\end{array}$ & $\begin{array}{l}49 . \\
1\end{array}$ & nd & nd & nd & $\begin{array}{l}52 . \\
74\end{array}$ \\
\hline $\begin{array}{l}2- \\
\text { Methylnaphthale } \\
\text { ne }\end{array}$ & $\begin{array}{l}17 . \\
09\end{array}$ & $\begin{array}{l}19 . \\
79\end{array}$ & $\begin{array}{l}17 . \\
79\end{array}$ & $\begin{array}{l}5.1 \\
8\end{array}$ & $\begin{array}{l}21 . \\
68\end{array}$ & $\begin{array}{l}10 . \\
38\end{array}$ & $\begin{array}{l}2.8 \\
3\end{array}$ & $\begin{array}{l}3.6 \\
6\end{array}$ & $\begin{array}{l}3.5 \\
4\end{array}$ & $\begin{array}{l}5.2 \\
9\end{array}$ & $\begin{array}{l}2.4 \\
2\end{array}$ & $\begin{array}{l}6.8 \\
3\end{array}$ & $\begin{array}{l}6.2 \\
4\end{array}$ & $\begin{array}{l}3.6 \\
6\end{array}$ & $\begin{array}{l}2.4 \\
2\end{array}$ & $\begin{array}{l}2.1 \\
8\end{array}$ \\
\hline Fluorene & $\begin{array}{l}2.3 \\
1\end{array}$ & $\begin{array}{l}2.1 \\
1\end{array}$ & $\begin{array}{l}2.4 \\
2\end{array}$ & $\begin{array}{l}2.3 \\
7\end{array}$ & $\begin{array}{l}1.8 \\
8\end{array}$ & $\begin{array}{l}2.1 \\
6\end{array}$ & $\begin{array}{l}2.4 \\
9 \\
\end{array}$ & $\begin{array}{l}2.1 \\
6\end{array}$ & $\begin{array}{l}2.0 \\
7 \\
\end{array}$ & $\begin{array}{l}7.5 \\
2\end{array}$ & $\begin{array}{l}2.2 \\
2\end{array}$ & $\begin{array}{l}2.3 \\
9\end{array}$ & $\begin{array}{l}7.3 \\
5\end{array}$ & $\begin{array}{l}7.1 \\
4\end{array}$ & $\begin{array}{l}7.1 \\
4\end{array}$ & $\begin{array}{l}7.6 \\
8\end{array}$ \\
\hline Phenanthrene & $\begin{array}{l}0.8 \\
2\end{array}$ & $\begin{array}{l}0.9 \\
6\end{array}$ & $\begin{array}{l}0.3 \\
9\end{array}$ & $\begin{array}{l}7.5 \\
0\end{array}$ & $\begin{array}{l}2.9 \\
9\end{array}$ & $\begin{array}{l}2.2 \\
7\end{array}$ & $\begin{array}{l}2.1 \\
8\end{array}$ & $\begin{array}{l}1.1 \\
6\end{array}$ & $\begin{array}{l}7.3 \\
3\end{array}$ & $\begin{array}{l}8.3 \\
8\end{array}$ & $\begin{array}{l}1.1 \\
0\end{array}$ & $\begin{array}{l}1.4 \\
3\end{array}$ & $\begin{array}{l}4.2 \\
2\end{array}$ & $\begin{array}{l}1.6 \\
6\end{array}$ & $\begin{array}{l}3.2 \\
3\end{array}$ & $\begin{array}{l}6.0 \\
8\end{array}$ \\
\hline Chrysene & $\begin{array}{l}0.0 \\
84\end{array}$ & nd & $\begin{array}{l}0.0 \\
78\end{array}$ & nd & $\begin{array}{l}0.0 \\
68\end{array}$ & nd & $\begin{array}{l}0.1 \\
2\end{array}$ & $\begin{array}{l}0.0 \\
65\end{array}$ & $\begin{array}{l}0.1 \\
8\end{array}$ & nd & $\begin{array}{l}0.0 \\
98\end{array}$ & $\begin{array}{l}0.0 \\
78\end{array}$ & nd & $\begin{array}{l}0.1 \\
7\end{array}$ & $\begin{array}{l}0.0 \\
7\end{array}$ & nd \\
\hline Fluoranthene & $\begin{array}{l}2.1 \\
7\end{array}$ & $\begin{array}{l}2.1 \\
9\end{array}$ & $\begin{array}{l}2.2 \\
1\end{array}$ & $\begin{array}{l}2.5 \\
2\end{array}$ & nd & $\begin{array}{l}2.3 \\
3\end{array}$ & $\begin{array}{l}2.2 \\
3\end{array}$ & $\begin{array}{l}1.7 \\
4\end{array}$ & $\begin{array}{l}2.1 \\
6\end{array}$ & $\begin{array}{l}11 . \\
04\end{array}$ & $\begin{array}{l}1.8 \\
4\end{array}$ & $\begin{array}{l}1.9 \\
0\end{array}$ & $\begin{array}{l}11 . \\
66\end{array}$ & $\begin{array}{l}11 . \\
5\end{array}$ & $\begin{array}{l}11 . \\
49\end{array}$ & $\begin{array}{l}12 . \\
47\end{array}$ \\
\hline Pyrene & $\begin{array}{l}9.8 \\
2\end{array}$ & $\begin{array}{l}9.6 \\
7\end{array}$ & $\begin{array}{l}10 . \\
41\end{array}$ & $\begin{array}{l}4.5 \\
5 \\
\end{array}$ & $\begin{array}{l}9.4 \\
7\end{array}$ & $\begin{array}{l}6.8 \\
9\end{array}$ & $\begin{array}{l}4.7 \\
3 \\
\end{array}$ & $\begin{array}{l}0.8 \\
0 \\
\end{array}$ & $\begin{array}{l}1.8 \\
8\end{array}$ & $\begin{array}{l}1.5 \\
9\end{array}$ & $\begin{array}{l}0.2 \\
6 \\
\end{array}$ & $\begin{array}{l}0.7 \\
4\end{array}$ & $\begin{array}{l}0.7 \\
3 \\
\end{array}$ & $\begin{array}{l}1.3 \\
7\end{array}$ & $\begin{array}{l}1.3 \\
0 \\
\end{array}$ & $\begin{array}{l}1.7 \\
2\end{array}$ \\
\hline $\begin{array}{l}\text { Benzo }(\mathrm{K}) \\
\text { Fluoranthene }\end{array}$ & nd & $\begin{array}{l}0.2 \\
5\end{array}$ & nd & $\begin{array}{l}0.0 \\
29\end{array}$ & $\begin{array}{l}0.3 \\
1\end{array}$ & $\begin{array}{l}0.0 \\
13\end{array}$ & nd & nd & $\begin{array}{l}0.8 \\
0\end{array}$ & nd & nd & nd & $\begin{array}{l}0.2 \\
2\end{array}$ & $\begin{array}{l}1.1 \\
3\end{array}$ & $\begin{array}{l}0.8 \\
5\end{array}$ & $\begin{array}{l}0.6 \\
2\end{array}$ \\
\hline $\begin{array}{l}\text { Indeno }(1,2,3- \\
\text { CD) Pyrene }\end{array}$ & $\begin{array}{l}4.6 \\
9\end{array}$ & $\begin{array}{l}4.3 \\
4\end{array}$ & $\begin{array}{l}4.8 \\
6\end{array}$ & $\begin{array}{l}4.5 \\
6\end{array}$ & $\begin{array}{l}3.4 \\
1\end{array}$ & $\begin{array}{l}4.2 \\
8\end{array}$ & $\begin{array}{l}5.4 \\
9\end{array}$ & $\begin{array}{l}4.5 \\
4\end{array}$ & $\begin{array}{l}4.2 \\
4\end{array}$ & $\begin{array}{l}5.6 \\
8\end{array}$ & $\begin{array}{l}4.6 \\
7\end{array}$ & $\begin{array}{l}4.8 \\
9\end{array}$ & $\begin{array}{l}6.8 \\
1\end{array}$ & $\begin{array}{l}7.1 \\
5\end{array}$ & $\begin{array}{l}6.5 \\
2\end{array}$ & $\begin{array}{l}6.8 \\
5\end{array}$ \\
\hline$\sum$ PAHs & $\begin{array}{l}36 . \\
99\end{array}$ & $\begin{array}{l}39 . \\
32\end{array}$ & $\begin{array}{l}38 . \\
17\end{array}$ & $\begin{array}{l}26 . \\
72\end{array}$ & $\begin{array}{l}39 . \\
8\end{array}$ & $\begin{array}{l}76 . \\
4\end{array}$ & $\begin{array}{l}73 . \\
33\end{array}$ & $\begin{array}{l}70 . \\
51\end{array}$ & $\begin{array}{l}22 . \\
22\end{array}$ & $\begin{array}{l}39 . \\
52\end{array}$ & $\begin{array}{l}53 . \\
87\end{array}$ & $\begin{array}{l}67 . \\
37\end{array}$ & $\begin{array}{l}37 . \\
23\end{array}$ & $\begin{array}{l}33 . \\
78\end{array}$ & $\begin{array}{l}33 . \\
04\end{array}$ & $\begin{array}{l}90 . \\
35\end{array}$ \\
\hline$\sum \mathrm{LMW}$ & $\begin{array}{l}20 . \\
22\end{array}$ & $\begin{array}{l}22 . \\
86\end{array}$ & $\begin{array}{l}20 . \\
6\end{array}$ & $\begin{array}{l}15 . \\
05\end{array}$ & $\begin{array}{l}26 . \\
54\end{array}$ & $\begin{array}{l}62 . \\
87\end{array}$ & $\begin{array}{l}60 . \\
76\end{array}$ & $\begin{array}{l}63 . \\
36\end{array}$ & $\begin{array}{l}12 . \\
95\end{array}$ & $\begin{array}{l}21 . \\
21\end{array}$ & $\begin{array}{l}46 . \\
99\end{array}$ & $\begin{array}{l}59 . \\
76\end{array}$ & $\begin{array}{l}17 . \\
81\end{array}$ & $\begin{array}{l}12 . \\
46\end{array}$ & $\begin{array}{l}12 . \\
79\end{array}$ & $\begin{array}{l}68 . \\
68\end{array}$ \\
\hline$\sum \mathrm{HMW}$ & $\begin{array}{l}16 . \\
76\end{array}$ & $\begin{array}{l}16 . \\
46\end{array}$ & $\begin{array}{l}17 . \\
57\end{array}$ & $\begin{array}{l}11 . \\
66\end{array}$ & $\begin{array}{l}13 . \\
25\end{array}$ & $\begin{array}{l}13 . \\
53\end{array}$ & $\begin{array}{l}12 . \\
56\end{array}$ & $\begin{array}{l}7.1 \\
4\end{array}$ & $\begin{array}{l}9.2 \\
7\end{array}$ & $\begin{array}{l}18 . \\
32\end{array}$ & $\begin{array}{l}6.8 \\
7\end{array}$ & $\begin{array}{l}7.6 \\
1\end{array}$ & $\begin{array}{l}19 . \\
42\end{array}$ & $\begin{array}{l}21 . \\
33\end{array}$ & $\begin{array}{l}20 . \\
24\end{array}$ & $\begin{array}{l}21 . \\
66\end{array}$ \\
\hline$\sum \mathrm{LMW} / \sum \mathrm{HMW}$ & $\begin{array}{l}1.2 \\
1\end{array}$ & $\begin{array}{l}1.3 \\
9\end{array}$ & $\begin{array}{l}1.1 \\
7\end{array}$ & $\begin{array}{l}1.2 \\
9\end{array}$ & $\begin{array}{l}2.0 \\
0\end{array}$ & $\begin{array}{l}4.6 \\
4\end{array}$ & $\begin{array}{l}4.8 \\
4\end{array}$ & $\begin{array}{l}8.8 \\
7\end{array}$ & $\begin{array}{l}1.3 \\
9\end{array}$ & $\begin{array}{l}1.1 \\
6\end{array}$ & $\begin{array}{l}6.8 \\
4\end{array}$ & $\begin{array}{l}7.8 \\
5\end{array}$ & $\begin{array}{l}0.9 \\
17\end{array}$ & $\begin{array}{l}0.5 \\
84\end{array}$ & $\begin{array}{l}0.6 \\
31\end{array}$ & $\begin{array}{l}3.1 \\
7\end{array}$ \\
\hline
\end{tabular}

nd $=$ no data

Table 3:- Polycyclic aromatic hydrocarbon (PAH) concentrations ( $\left.\mathrm{ng} \mathrm{g}^{-1} \mathrm{dw}\right)$ at sampling stations in the Sabancuy area.

\begin{tabular}{|c|c|c|c|c|c|c|c|c|c|c|c|c|c|c|c|c|}
\hline & \multicolumn{6}{|c|}{ Mangrove Forest } & \multicolumn{6}{|c|}{ Interior Sabancuy Lagoon } & \multicolumn{4}{|c|}{ Coastal Zone } \\
\hline PAHs & P1 & P2 & P3 & P4 & P5 & P6 & P7 & P8 & P9 & $\begin{array}{l}\text { P1 } \\
\text { 0 }\end{array}$ & $\begin{array}{l}\text { P1 } \\
1\end{array}$ & $\begin{array}{l}\text { P1 } \\
2\end{array}$ & $\begin{array}{l}\text { P1 } \\
3\end{array}$ & $\begin{array}{l}\text { P1 } \\
4\end{array}$ & $\begin{array}{l}\text { P1 } \\
5\end{array}$ & $\begin{array}{l}\text { P1 } \\
6\end{array}$ \\
\hline Fluorene & $\begin{array}{l}3.5 \\
7\end{array}$ & $\begin{array}{l}3.8 \\
7\end{array}$ & $\begin{array}{l}6.8 \\
5\end{array}$ & $\begin{array}{l}6.2 \\
4\end{array}$ & $\begin{array}{l}5.9 \\
5\end{array}$ & $\begin{array}{l}3.2 \\
4\end{array}$ & $\begin{array}{l}5.9 \\
6\end{array}$ & $\begin{array}{l}5.0 \\
2\end{array}$ & $\begin{array}{l}6.6 \\
8\end{array}$ & $\begin{array}{l}6.6 \\
4\end{array}$ & $\begin{array}{l}5.2 \\
2\end{array}$ & $\begin{array}{l}6.6 \\
4\end{array}$ & $\begin{array}{l}6.7 \\
4\end{array}$ & $\begin{array}{l}5.3 \\
7\end{array}$ & $\begin{array}{l}7.6 \\
0\end{array}$ & $\begin{array}{l}3.3 \\
1\end{array}$ \\
\hline Phenanthrene & nd & $\begin{array}{l}2.6 \\
4\end{array}$ & $\begin{array}{l}9.3 \\
9\end{array}$ & $\begin{array}{l}3.3 \\
4\end{array}$ & $\begin{array}{l}1.1 \\
9\end{array}$ & $\begin{array}{l}1.5 \\
0\end{array}$ & $\begin{array}{l}1.4 \\
1\end{array}$ & $\begin{array}{l}1.0 \\
9\end{array}$ & $\begin{array}{l}0.3 \\
0\end{array}$ & $\begin{array}{l}1.0 \\
4\end{array}$ & $\begin{array}{l}1.5 \\
8\end{array}$ & $\begin{array}{l}1.6 \\
1\end{array}$ & $\begin{array}{l}1.8 \\
5\end{array}$ & $\begin{array}{l}1.1 \\
5\end{array}$ & $\begin{array}{l}2.1 \\
7 \\
\end{array}$ & $\begin{array}{l}2.5 \\
5\end{array}$ \\
\hline Fluoranthene & $\begin{array}{l}5.0 \\
7\end{array}$ & $\begin{array}{l}5.4 \\
9\end{array}$ & $\begin{array}{l}9.3 \\
7\end{array}$ & $\begin{array}{l}8.9 \\
8\end{array}$ & $\begin{array}{l}8.5 \\
5\end{array}$ & $\begin{array}{l}4.6 \\
4\end{array}$ & $\begin{array}{l}7.5 \\
7\end{array}$ & $\begin{array}{l}7.1 \\
2\end{array}$ & $\begin{array}{l}8.8 \\
9\end{array}$ & $\begin{array}{l}8.3 \\
4\end{array}$ & $\begin{array}{l}6.8 \\
3\end{array}$ & $\begin{array}{l}7.3 \\
7\end{array}$ & $\begin{array}{l}8.9 \\
2\end{array}$ & $\begin{array}{l}6.9 \\
7\end{array}$ & $\begin{array}{l}9.7 \\
6\end{array}$ & $\begin{array}{l}4.5 \\
5\end{array}$ \\
\hline Pyrene & nd & nd & 10. & 6.9 & 8.4 & 2.0 & 4.1 & 4.5 & 1.3 & 2.9 & 4.2 & 2.5 & 3.8 & 2.0 & 1.8 & 8.9 \\
\hline
\end{tabular}




\begin{tabular}{|c|c|c|c|c|c|c|c|c|c|c|c|c|c|c|c|c|}
\hline & & & 72 & 7 & 6 & 3 & & 7 & 4 & 0 & 6 & 6 & 9 & 5 & 9 & 5 \\
\hline $\begin{array}{l}\text { Dibenzo (A, H) } \\
\text { Anthracene }\end{array}$ & 8.3 & $\begin{array}{l}8.9 \\
4\end{array}$ & $\begin{array}{l}14 . \\
91\end{array}$ & $\begin{array}{l}15 . \\
27\end{array}$ & $\begin{array}{l}14 . \\
26\end{array}$ & $\begin{array}{l}7.5 \\
2\end{array}$ & $\begin{array}{l}11 . \\
54\end{array}$ & $\begin{array}{l}11 . \\
39\end{array}$ & $\begin{array}{l}14 . \\
59\end{array}$ & $\begin{array}{l}11 . \\
71\end{array}$ & $\begin{array}{l}10 . \\
21\end{array}$ & $\begin{array}{l}8.1 \\
0\end{array}$ & $\begin{array}{l}14 . \\
21\end{array}$ & $\begin{array}{l}10 . \\
55\end{array}$ & $\begin{array}{l}15 . \\
05\end{array}$ & $\begin{array}{l}7.3 \\
1\end{array}$ \\
\hline $\begin{array}{l}\text { Benzo }(\mathrm{G}, \mathrm{H}, \mathrm{I}) \\
\text { Perylene }\end{array}$ & nd & nd & $\begin{array}{l}0.4 \\
3\end{array}$ & $\begin{array}{l}0.7 \\
7\end{array}$ & nd & nd & 1.0 & nd & $\begin{array}{l}0.0 \\
6\end{array}$ & $\begin{array}{l}0.1 \\
7\end{array}$ & nd & nd & $\begin{array}{l}0.2 \\
8\end{array}$ & nd & $\begin{array}{l}0.0 \\
3\end{array}$ & nd \\
\hline $\begin{array}{l}\text { Indeno }(1,2,3- \\
\text { CD) Pyrene }\end{array}$ & nd & nd & $\begin{array}{l}2.3 \\
8\end{array}$ & nd & nd & nd & nd & nd & nd & $\begin{array}{l}0.1 \\
3\end{array}$ & nd & nd & nd & nd & $\begin{array}{l}0.0 \\
9\end{array}$ & nd \\
\hline$\sum$ PAHs & $\begin{array}{l}16 . \\
95\end{array}$ & $\begin{array}{l}20 . \\
95\end{array}$ & $\begin{array}{l}54 . \\
0\end{array}$ & $\begin{array}{l}41 . \\
58\end{array}$ & $\begin{array}{l}38 . \\
4\end{array}$ & $\begin{array}{l}18 . \\
94\end{array}$ & $\begin{array}{l}31 . \\
58\end{array}$ & $\begin{array}{l}29 . \\
19\end{array}$ & $\begin{array}{l}31 . \\
88\end{array}$ & $\begin{array}{l}30 . \\
93\end{array}$ & $\begin{array}{l}28 . \\
09\end{array}$ & $\begin{array}{l}26 . \\
28\end{array}$ & $\begin{array}{l}35 . \\
89\end{array}$ & $\begin{array}{l}26 . \\
1\end{array}$ & $\begin{array}{l}36 . \\
59\end{array}$ & $\begin{array}{l}26 . \\
68\end{array}$ \\
\hline$\sum \mathrm{LMW}$ & $\begin{array}{l}3.5 \\
7\end{array}$ & $\begin{array}{l}6.5 \\
1 \\
\end{array}$ & $\begin{array}{l}16 . \\
23\end{array}$ & $\begin{array}{l}9.5 \\
8\end{array}$ & $\begin{array}{l}7.1 \\
3\end{array}$ & $\begin{array}{l}4.7 \\
4\end{array}$ & $\begin{array}{l}7.3 \\
7\end{array}$ & $\begin{array}{l}6.1 \\
1 \\
\end{array}$ & $\begin{array}{l}6.9 \\
9 \\
\end{array}$ & $\begin{array}{l}7.6 \\
7 \\
\end{array}$ & $\begin{array}{l}6.7 \\
9 \\
\end{array}$ & $\begin{array}{l}8.2 \\
5 \\
\end{array}$ & $\begin{array}{l}8.5 \\
9 \\
\end{array}$ & $\begin{array}{l}6.5 \\
2 \\
\end{array}$ & $\begin{array}{l}9.7 \\
7 \\
\end{array}$ & $\begin{array}{l}5.8 \\
6 \\
\end{array}$ \\
\hline$\sum \mathrm{HMW}$ & $\begin{array}{l}13 . \\
37\end{array}$ & $\begin{array}{l}14 . \\
43\end{array}$ & $\begin{array}{l}37 . \\
81\end{array}$ & $\begin{array}{l}32 . \\
0\end{array}$ & $\begin{array}{l}31 . \\
27\end{array}$ & $\begin{array}{l}14 . \\
19\end{array}$ & $\begin{array}{l}24 . \\
21\end{array}$ & $\begin{array}{l}23 . \\
1\end{array}$ & $\begin{array}{l}24 . \\
89\end{array}$ & $\begin{array}{l}23 . \\
26\end{array}$ & $\begin{array}{l}21 . \\
29\end{array}$ & $\begin{array}{l}18 . \\
03\end{array}$ & $\begin{array}{l}27 . \\
31\end{array}$ & $\begin{array}{l}19 . \\
58\end{array}$ & $\begin{array}{l}26 . \\
83\end{array}$ & $\begin{array}{l}20 . \\
82\end{array}$ \\
\hline$\sum \mathrm{LMW} / \sum \mathrm{HMW}$ & $\begin{array}{l}0.2 \\
67\end{array}$ & $\begin{array}{l}0.4 \\
51\end{array}$ & $\begin{array}{l}0.4 \\
29\end{array}$ & $\begin{array}{l}0.2 \\
99\end{array}$ & $\begin{array}{l}0.2 \\
28\end{array}$ & $\begin{array}{l}0.3 \\
34\end{array}$ & $\begin{array}{l}0.3 \\
04\end{array}$ & $\begin{array}{l}0.2 \\
64\end{array}$ & $\begin{array}{l}0.2 \\
81\end{array}$ & $\begin{array}{l}0.3 \\
29\end{array}$ & $\begin{array}{l}0.3 \\
19\end{array}$ & $\begin{array}{l}0.4 \\
57\end{array}$ & $\begin{array}{l}0.3 \\
14\end{array}$ & $\begin{array}{l}0.3 \\
33\end{array}$ & $\begin{array}{l}0.3 \\
64\end{array}$ & $\begin{array}{l}0.2 \\
81\end{array}$ \\
\hline
\end{tabular}

nd $=$ no data

Polycyclic aromatic hydrocarbons (PAHs) occur naturally in fossil fuels (coal and oil) and are produced as combustion by-products; in other words, they can be of natural or anthropogenic origin. The molecular index of PAHs has been widely used to identify PAH source in sediment samples. Distribution of PAHs varies according to the production source, organic matter composition and combustion temperature. Molecular index data can be compared to $\mathrm{PAH}$ concentration ratios to differentiate those of pyrolytic and petrogenic origin. A specific PAH ratio (fluoranthene/ fluoranthene + pyrene) was calculated using the present data. Low ratio values $(<0.40)$ indicate the presence of oil and its derivatives, intermediate values (0.4-0.5) indicate combustion of liquid fossil fuels (e.g. gasolines and crude oil), and values $>0.5$ result from combustion of grasslands, forests and charcoal (Yunker and Macdonald, 2003).

Pyrolytic-origin PAHs are produced by the incomplete combustion of fossil fuels and/or organic material, and are normally emitted in the form of vehicle exhaust or other related products (e.g. asphalt). The products produced by a combustion event depend largely on fuel material, temperature, and the fuel/air ratio, but they generally contain high percentages of PAHs with four or more rings (Tolga-Gonul and Filiz-Kucuksezgin 2012). In the present results, this type of PAH was most frequent in the Sabancuy region (38.80\%) followed by Isla del Carmen $(21.49 \%)$ and Isla Aguada (11.21\%) (Fig. 4).

Diagenic-origin aliphatic and aromatic hydrocarbons contain two-ring hydrocarbons and come from sources such as terrestrial plant derivatives, marine phytoplankton and seed oils. This type of hydrocarbon had a major influence in the Isla Aguada stations (55.45 \%) followed by those near Isla del Carmen (35.73\%). None were detected in the Sabancuy area (Fig. 4).

In summary, the specific PAH ratio (fluoranthene / fluoranthene + pyrene) results indicate that the Sabancuy stations (index $>0.5$ ) contained hydrocarbons resulting from the burning of grasslands as part of local agricultural practices and/or of trash. The Isla Aguada stations (index >0.5) contained hydrocarbons of mixed origin, mostly from fossil fuel combustion and the burning of grasslands. Notably different from the other two regions, the Isla del Carmen stations $(<0.4)$ had a ratio clearly indicating hydrocarbons originating in spills of crude oil and refined petroleum products (Fig. 4). 


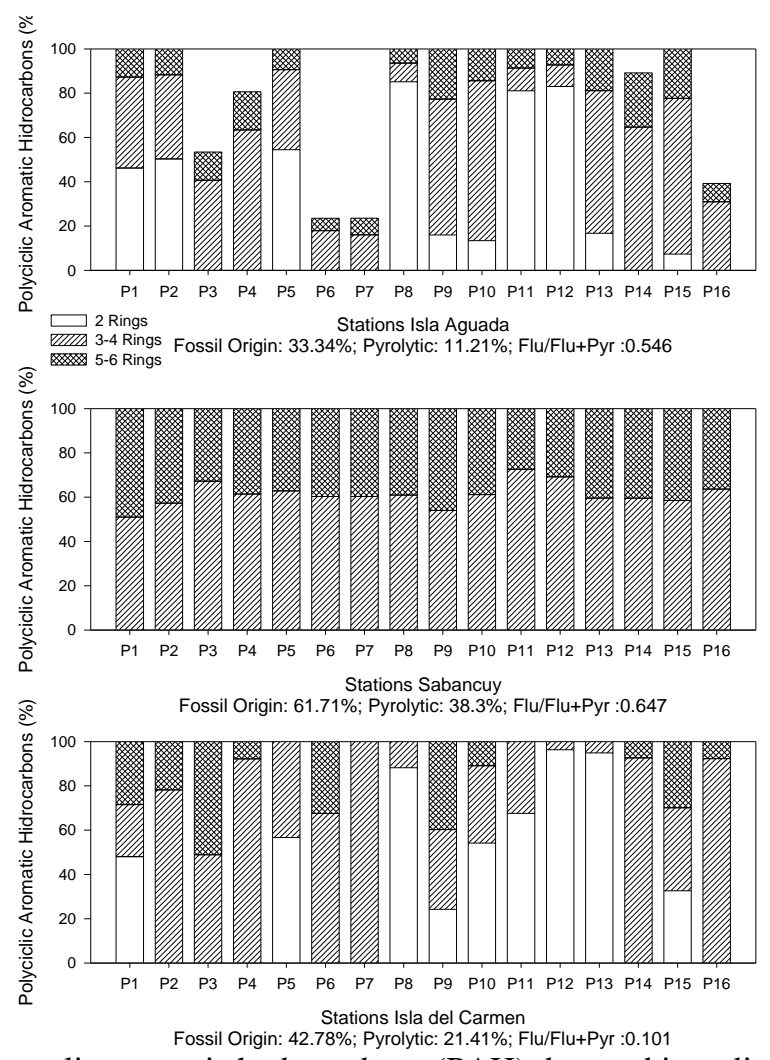

Fig. 4:- Proportions of polycyclic aromatic hydrocarbons (PAH) detected in sediments at Isla del Carmen, Isla Aguada and Sabancuy, classified by number of rings (Flu: fluoranthene, Pyr: Pyrene).

\section{Sediment contamination evaluation based on biological thresholds:-}

The potential toxicity for aquatic organisms of the PAHs in surface sediment detected in the present study were evaluated using two guidelines (Table 4): low-range (LRE) and mid-range effects (MRE) (Long et al. 1995); and threshold effects (TEL) and probable effects levels (PEL) (Macdonald et al. 1996). Based on the first set of criteria (Long et al. 1995), PAH concentrations below the LRE value represent a range of minimum effects, that is, negative effects would rarely be observed. Concentrations equal to or above the LRE value, but below the MRE value represent a range within which effects would be possible but irregularly observed. Concentrations equal to or greater than the MRE represent a range of frequently occurring probable effects. Under the second set of criteria (Macdonald et al. 1996), PAH concentrations below the TEL would rarely cause adverse biological effects, therefore indicating a high protection level for aquatic organisms. Concentrations higher than the PEL greatly increase the probability and frequency of adverse biological effects, representing a low protection level.

Mean total PAH ( $\left.\sum \mathrm{PAH}\right)$ concentration in mangrove sediment was $41.29 \mathrm{ng} \mathrm{g}^{-1} \mathrm{dw}$ at Isla de Carmen, $48.67 \mathrm{ng} \mathrm{g}^{-1}$ $\mathrm{dw}$ at Isla Aguada, and $30.88 \mathrm{ng} \mathrm{g}^{-1} \mathrm{dw}$ at Sabancuy. All are well below the values proposed for LRE $\left(4,022 \mathrm{ng} \mathrm{g}^{-1}\right.$ $\mathrm{dw}$ ) and TEL (655 $\left.\mathrm{ng} \mathrm{g}^{-1} \mathrm{dw}\right)$, meaning the recorded levels would have minimum effects and would be unlikely to cause adverse biological effects in aquatic organisms (Long et al. 1995; Macdonald et al. 1996) (Table 4).

Certain individual PAHs exhibited relatively high values in specific areas. Acenapthene at the Isla del Carmen stations was present at $26.22 \mathrm{ng} \mathrm{g}^{-1} \mathrm{dw}$, a level exceeding the TEL but below the PEL, LRE and MRE levels. It therefore represents a low level of potential biological effects. The average $\left(50.13 \mathrm{ng} \mathrm{g}^{-1} \mathrm{dw}\right)$ and maximum $(56.38$ $\mathrm{ng} \mathrm{g}^{-1} \mathrm{dw}$ ) acenapthene levels at the Isla Aguada stations were higher than the LRE and TEL values but still lower than the MRE and PEL values. This represents a possible range of irregular effects. At Sabancuy, dibenzo (a,h) anthracene (11.49 $\mathrm{ng} \mathrm{g}^{-1} \mathrm{dw}$ ) had a concentration above the TEL, suggesting the irregular occurrence of adverse biological effects. 
Table 4:- Proposed polycyclic aromatic hydrocarbon (PAH) contamination criteria for sediments.

\begin{tabular}{|c|c|c|c|c|c|c|c|c|}
\hline \multirow[t]{3}{*}{ PAHs } & \multicolumn{2}{|c|}{$\begin{array}{l}\text { Sediment quality } \\
\left.\text { guidelines (ng g } \mathbf{g}^{-1} \mathbf{d w}\right)\end{array}$} & \multicolumn{6}{|c|}{ PAH concentrations in sediment $\left(\mathrm{ng} \mathrm{g}^{-1} \mathrm{dw}\right)$} \\
\hline & & & Isla de & Carmen & Isla $A \xi$ & ada & Sabanc & \\
\hline & $\begin{array}{ll}\text { LRE } & - \\
\text { MRE } & \end{array}$ & $\begin{array}{l}\text { TEL } \quad- \\
\text { PEL }\end{array}$ & Men & Maximum & Men & Maximum & Men & Maximum \\
\hline Acenaphthene & $44-640$ & $6-128$ & 26.22 & 47.62 & 50.13 & 56.38 & - & - \\
\hline 2-Methylnaphthalene & - & - & - & - & 8.18 & 21.68 & - & - \\
\hline Anthracene & $85-1100$ & $47-245$ & - & - & - & - & - & - \\
\hline Fluorene & $19-540$ & $21-144$ & 17.44 & 28.25 & 3.84 & 7.68 & 5.56 & 7.6 \\
\hline Phenanthrene & $\begin{array}{ll}240 & - \\
1500\end{array}$ & $87-544$ & - & - & 3.23 & 8.38 & 2.19 & 9.38 \\
\hline Chrysene & $\begin{array}{ll}384 & - \\
2800\end{array}$ & $108-846$ & - & - & 0.1 & 0.17 & - & - \\
\hline Fluoranthene & $\begin{array}{l}600 \\
5100\end{array}$ & $\begin{array}{ll}113 & - \\
1494 & \end{array}$ & 1.48 & 2.82 & 5.29 & 12.47 & 7.40 & 9.75 \\
\hline Pyrene & $\begin{array}{l}665 \\
2600\end{array}$ & $\begin{array}{ll}153 \quad- \\
1398\end{array}$ & 4.12 & 10.41 & 4.12 & 10.41 & 4.62 & 10.72 \\
\hline $\begin{array}{ll}\text { Benzo } & (\mathrm{k}) \\
\text { Fluoranthene } & \end{array}$ & - & - & - & - & 0.47 & 1.13 & - & - \\
\hline $\begin{array}{ll}\text { Dibenzo } & (\mathrm{a}, \mathrm{h}) \\
\text { Anthracene } & \end{array}$ & $63-260$ & $6-135$ & 1.91 & 3.08 & - & - & 11.49 & 15.27 \\
\hline Benzo $(\mathrm{g}, \mathrm{h}, \mathrm{i})$ Perylene & - & - & - & - & - & - & 0.39 & 1 \\
\hline $\begin{array}{l}\text { Indeno } \quad(1,2,3-\mathrm{cd}) \\
\text { Pyrene }\end{array}$ & - & - & 13.81 & 43.35 & 5.19 & 7.15 & 0.87 & 2.37 \\
\hline$\sum \mathrm{PAHs}$ & $\begin{array}{l}4022- \\
44792\end{array}$ & $\begin{array}{l}655 \\
6676\end{array}$ & 41.29 & 99.22 & 48.67 & 90.34 & 30.88 & 54.04 \\
\hline
\end{tabular}

\section{Conclusions:-}

The PAHs found in the sediments of the coastal and mangrove zones of the Isla del Carmen and Isla Aguada areas were largely LMW and of both pyrolytic and petrogenic sources. In contrast, Sabancuy sediments contained mostly HMW PAHs. All three areas exhibited higher sediment hydrocarbon contents due to oil industry activities in the region (e.g. accidental spills; oil industry ship and small craft traffic), although the burning of fossil fuels, grasslands, forest and charcoal did contribute to a lesser degree. Several PAHs were identified at the sampling stations, but none of the analyzed sediments met the LRE-MRE or TEL-PEL criteria used to classify sediments as contaminated. Sediments in the study area can therefore be considered uncontaminated with hydrocarbons, are unlikely to cause even irregular adverse biological effects and pose no threat to aquatic organisms. Incomplete combustion of organic matter, be it from natural or anthropogenic causes, is the main contributor to PAH concentrations in the environment. Although none of the levels recorded here exceeded maximum permissible levels for specific hydrocarbons in sediments, they may yet pose a threat to the trophic chain. Determining the extent of this potential threat will require further research in various disciplines. The present study constitutes an important principal data source for future studies into PAH distribution in the region's coastal and mangrove sediments.

\section{Acknowledgment:-}

This study was financially supported by Consejo Nacional de Ciencia y Tecnologia (CONACYT) Mexico (N0. 095188). 


\section{References:-}

1. Agrawala S, Ota T, Risbey J, Hagenstand M, Smith J, Aalst Mv, Koshy K, Prasad B (2004) Development and climate change in Egypt: focus on coastal resources and the Nile. Environment Directorate and Development Cooperation Directorate, Organization for Economic Cooperation and Development (OECD), Paris

2. Bicego MC, Taniguchi S, Yogui GT, Montone RC, da Silva DAM, Lourenco RA, Martins CDC, Sasaki ST, Pellizari VH, Weber RR (2006) Assessment of contamination by polychlorinated biphenyls and aliphatic and aromatic hydrocarbons in sediments of the Santos and Sao Vicente Estuary System, Sao Paulo, Brazil. Mar Pollut Bull 52:1784-1832

3. Cavalcante RM, Sousa FW, Nascimento RF, Silveira ER, Freire GSS (2009) The impact of urbanization on tropical mangroves (Fortaleza, Brazil): Evidence from PAH distribution in sediment. J Environ Manage 91(2):328-335

4. Commendatore MG, Nievas ML, Amin O, Esteves JL (2012) Sources and distribution of aliphatic and polyaromatic hydrocarbons in coastal sediments from the Ushuaia Bay (Tierra del Fuego, Patagonia, Argentina). Marine Environmental Research 74:20-31

5. Companioni-Damas EY, Nuñez-Clementel AC, Cora-Medina MO, Rosabal-Rodriguez M, Gonzalez-Bravo L, Marbot-Ramada R, Montes de Oca-Porto R, Diaz-Diaz MA (2011) Anthropogenic hydrocarbons in sediments of the northeastern Havana seaboard. Ciencias Marinas 37(2):227-235

6. Chen JL, Wong YS, Tam NFY (2009) Static and dynamic sorption of phenanthrene in mangrove sediment slurry. J Hazardous Mater 168(23):1422-1429

7. De la Lanza-Espino G, Lozano-Montes H (1999) Comparación fisicoquímica de las lagunas de Alvarado y Términos. Hidrobiológica 9: 15-30

8. DeLaune RD, Hambrick GA, Patrick WH (1980) Degradation of hydrocarbons in oxidized and reduced sediments. Mar Pollut Bull 11(4):103-106

9. Gogou A, Bouloubassi I, Stephanou EG (2000) Marine organic geochemistry of the Eastern Mediterranean: 1. Aliphatic and polyaromatic hydrocarbons in Cretan Sea surficial sediments. Mar Chem 68:265-282

10. Gonul TL, Kucuksezgin F (2012) Aliphatic and polycyclic aromatic hydrocarbons in the surface sediments from the Eastern Aegean: assessment and source recognition of petroleum hydrocarbons. Environ Sci Pollut Res 19: 31-41

11. Haritash AK, Kaushik CP (2009) Biodegradation aspects of polycyclic aromatic hydrocarbons (PAHs): a review. J Hazard Mater 169(1-3):1-15

12. Haapkylä J, Ramade F, Salvat B (2007) Oil pollution on coral reefs: a review of the state of knowledge and management needs. Vie et Milieu - Life and Environment 57(1/2): 91-107.

13. Hu NJ, Huang P, Liu JH, Ma DY, Shi XF, Mao J, Liu Y (2014) Characterization and source apportionment of polycyclic aromatic hydrocarbons (PAHs) in sediments in the Yellow River Estuary, China. Environ Earth Sci 71:873-883

14. INEGI (Instituto Nacional de Estadística Geografía e Informática) (National Institute of Statistic, Geography and Computer Science) (2010) Consulted 15 April 2016

15. Rosario Iturbe, Alejandrina Castro, Guillermina Perez, Carlos Flores, Luis G. Torres (2007) TPH and PAH concentrations in the subsoil of polyduct segments, oil pipeline pumping stations, and right-of-way pipelines from Central Mexico. Environ Geol, DOI 10.1007/s00254-007-1129-4

16. Jiries A, Hussain H, Lintelmann J (2000) Determination of polycyclic aromatic hydrocarbons in wastewater, sediment, sludge and plants in Karak Province, Jordan. Water, Air and Soil Pollution 121: 217-228.

17. Li BH, Feng CH, Li X, Chen YX, Niu JF, Shen ZY (2012) Spatial distribution and source apportionment of PAHs in surficial sediments of the Yangtze Estuary, China. Mar Pollut Bill 63(3):636-643

18. Long E, MacDonald D, Smith S, Calder F (1995) Incidence of adverse biological effects within ranges of chemical concentration in marine and estuarine sediments. Environ Manag 19(1):81-97

19. Macdonald DD, Carr RS, Calder FD, Long ER, Ingersoll CG (1996) Development and evaluation of sediment quality guidelines for Florida coastal water. Ecotoxicology 5(4):253-278

20. Maliszewska-Kordybach B (2005) Dissipation of polycyclic aromatic hydrocarbons in freshly contaminated soils-the effect of soil physicochemical properties and aging. Water, Air and Soil Pollution 168:13-128

21. Martins CC, Bicego MC, Taniguchi S, Montone RC (2004) Aliphatic and polycyclic aromatic hydrocarbons in surface sediments in Admiralty Bay, King George Island, Antarctica. Antarct Sci 16(2):117-122

22. NOM-138-SEMARNAT/SSA1-2012, Límites Máximos Permisibles de Hidrocarburos en Suelos y lineamientos para el muestreo en la caracterización y especificaciones para la remediación, (2012).

23. Oil Spill Intelligence Reports (OSIR) (1999) Oil Spill risks in Latin America and Caribbean Region. White Paper Ser, Techn Statist Anal Cutter Information Corp, September 1999. 
24. Pozo K, Perra G, Menchi V, Urrutia R, Parra O, Rudolph A, Focardi S (2011) Levels and spatial distribution of polycyclic aromatic hydrocarbons (PAHs) in sediments from Lenga Estuary, Central Chile. Mar Pollut Bull 62(7):1572-1576

25. Qiao M, Wang C, Huang S, Wang D, Wang Z (2006) Composition, source, and potential toxicological significance of PAHs in the surface sediments of the Meiliang Bay, Taihu Lake, China. Environ Int 32(1):28-33

26. Ramade F, Roche H (2006) Ecotoxicological impingement of pollutants on coral reefs: a review. Rev Ecol Terre Vie 61 (1): 3-33.

27. Ramade F (2000) Dictionnaire encyclopédique des pollutions. Edi Science International Paris, $1999,640 \mathrm{p}$

28. Raza M, Zakaria MP, Hashim NR, Yim UH, Kannan N, Ha SY (2013) Composition and source identification of polycyclic aromatic hydrocarbons in mangrove sediments of Peninsular Malaysia indication of anthropogenic input. Environ Earth Sci 70:2425-2436.

29. Readman JW, Mantoura RFC, Rhead MM (1984) The physicochemical speciation of polycyclic aromatic hydrocarbons (PAH) in aquatic systems. Fresenius Z Anal Chem 319:126-131

30. Readman JW, Fillmann G, Tolosa I, Bartocci J, Villeneuve JP, Catinni C, Mee JW (2002) Petroleum and PAH contamination of the Black Sea. Mar Pollut Bull 44:48-62

31. Ruiz-Marín A, Canedo-López Y, Zavala-Loría JC, García-Sarracino Reyes, Anguebes-Franseschi F, CordovaQuiroz VA (2014) Variation on the Fluxes of Nutrients in an Urban Lagoon by Seasonal Effects and Human Activities. Hydrol Current Res 5(2): 1-8, doi:10.4172/2157-7587.1000170

32. Tam NFY, Ke L, Wang XH, Wong YS (2001) Contamination of polycyclic aromatic hydrocarbons in surface sediments of mangrove swamps. Environ Pollut 114(2):255-263

33. Tian Y, Liu HJ, Zheng TL, Kwon KK, Kim SJ, Yan CL (2008) PAHs contamination and bacterial communities in mangrove surface sediments of the Jiulong River Estuary, China. Mar Pollut Bull 57(6-12):707-715

34. Tolga-Gonul L, Filiz-Kucuksezgin (2012) Aliphatic and polycyclic aromatic hydrocarbons in the surface sediments from the Eastern Aegean: assessment and source recognition of petroleum hydrocarbons. Envrion Sci Pollut Res 19: 31-41.

35. Tolosa I, Mora S, Sheikholeslami MR, Villeneuve JP, Bartocci J, Cattini C (2004) Aliphatic and aromatic hydrocarbons in coastal Caspian Sea sediments. Mar Pollut Bull 49: 44-60.

36. Volkman JK, Holdswoeth DG, Neill GP, Bavor HJ (1992) Identification of natural, anthropogenic and petroleum hydrocarbons in aquatic sediments. The Science of Total Environment 112: 203-219

37. Wang Z, Liu M, Yang Y (2015) Characterization and source analysis of polycyclic aromatic hydrocarbons in surface sediments in the Yangtze River Estuary. Environ Earth Sci 73:2453-2462

38. Zhi-qiang LU, Wen-jiao Z, Li MA (2005) Bioconcentration of polycyclic aromatic hydrocarbons in roots of three mangrove specie in Jiulong River Estuary. J Environ Sci 17(2):285-289

39. Yunker MB, Macdonald RW (2003) Alkane and PAH depositional history, source and fluxes in sediments from the Fraser River Basin and Strait of Georgia, Canada. Org Geochem 34:1429-1454. 